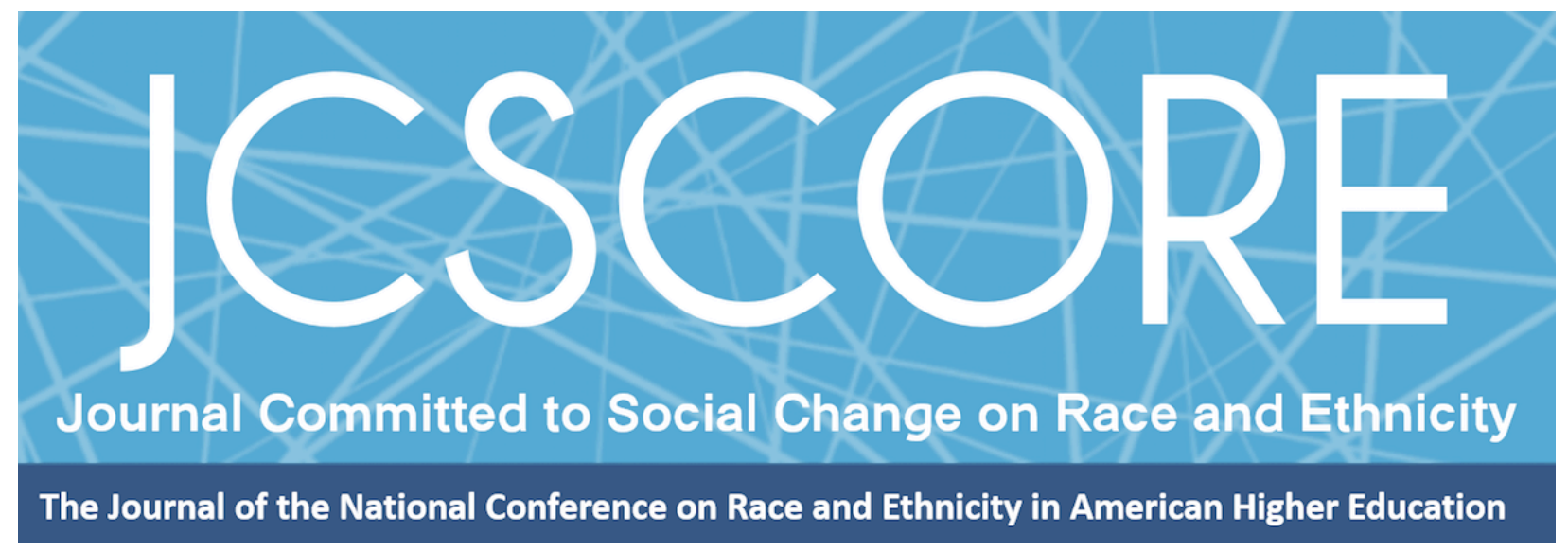

\title{
AWARENESS, SENSITIVITY AND CHECKING OUR PRIVILEGE ARE NOT ENOUGH: REFLECTIONS ON WHITENESS AND AMERICAN HIGHER EDUCATION
}

Tim Wise

Journal Committed to Social Change on Race and Ethnicity

Volume 1, Issue 1 | 2015

Copyright $\odot 2015$ Board of Regents of The University of Oklahoma on behalf of the Southwest Center for Human Relations Studies.

Permission of the Publisher is required for resale or distribution and for all derivative works, including compilations and translations. Quoting small sections of text is allowed as long as there is appropriate attribution. 


\section{Awareness, Sensitivity and Checking Our Privilege are Not Enough: Reflections on Whiteness and American Higher Education}

It has been twenty years this past March since I stepped onto the campus at Northeastern Illinois University, having been invited by a sociology professor there to speak to her classes about racism in America. A day later I conducted a training with local high school teachers at the Chicago Teacher's Center on the same subject, followed three weeks later by sojourns to Kansas City Community College and the University of Kansas, at which places I addressed the intersectionality of racism, sexism and heterosexism, both within the academy and in the larger society. With that first month on the lecture circuit behind me, I had officially joined the ranks of a loosely knit band of educators and activists who travel the country speaking about our particular areas of expertise to any audience that might have us. In my case, five years of grassroots activism and antiracism organizing in New Orleans had apparently qualified me for the designation of "expert" when it came to the subject of race-a manifestation of substantial white male privilege if ever the concept had meaning, as I have discussed before (Wise, 2010; Singley, 2002; Thompson, Schaefer \& Brod, 2003)—and thus it began: the journey that has for the past two decades kept me moving, meeting with students, teachers, community activists and others to discuss the significance of race in modern America.

Over the course of those twenty years, I have had the luxury of observing the world of higher education from a position that few others have enjoyed. Rather than working on one, or perhaps a few campuses-as is the case for most academic race 
scholars-I have been able to witness the evolution (or lack thereof) of American higher education in regards to race in hundreds of locations and on many different types of college environments, from community and technical colleges to large four-year state institutions to elite private Universities in every state of the union. I have had the chance to pay special attention to the way that whiteness, as a personal identity and social force, is lived in those spaces. As an antiracist educator much buoyed by the work of academic scholars, though not an academic myself, I have been able to observe quite closely the way in which whiteness is discussed (or not discussed), challenged (or not challenged) by two generations of college students.

Persons with whom I spoke in 1995 would by now be in their late thirties or early forties, many with their own families and children. Indeed, some of them likely have children on the precipice of entering college themselves in a few years. Given such a passage of time, it seems appropriate to ask: How has American higher education changed in the past two decades, in terms of the way it approaches matters of race?

Admittedly as an outsider to the academy, I am in no position to pontificate on this question from an academic perspective. I have conducted no studies on the matter, run no regression analyses, and developed no survey instruments with which I might discern some quantifiable truth on these matters. And yet, as someone who has spoken on at least 750 college campuses in that twenty-year period-several of them multiple times_and met with students both white and of color to discuss race and racism, perhaps my experiences as an antiracist practitioner if not academic will yet prove insightful. Though a bird's eye view to be sure, flying in and out of those campuses having dwelled at each for only a day or two typically, I would nonetheless think that 
after a while such a bird as that can gain a fairly decent sense of the ground below, and how the terrain may have changed over time, or not changed, as the case may be.

In some ways, the United States of 2015 is a far different place from what it was in 1995. First, it is considerably less white. In 1995, non-Hispanic whites (as we are called by the Census Bureau) were seventy-four percent of the nation's population (U.S. Bureau of the Census, 1996) whereas today, that number has fallen to around $64 \%$. African Americans, then as now, represent(ed) between 12.5 and $13 \%$ of the population, but the share of the population that is Latino/a has jumped considerably, from only a little over $10 \%$ twenty years ago, to about $18 \%$ in 2015 (U.S. Bureau of the Census, 2014). Additionally, Barack Obama—who in 1995 was just a few years out of Harvard Law School-is now, as I write this, in the last eighteen months of his second term as president: the nation's first Commander-in-Chief of color. Though the demographic shift was predicted at least as far back as the mid-1990s, it would be no exaggeration to suggest that its magnitude, along with the political rise of Obama and the further development of a thoroughly multicultural popular culture-from music to fashion to cuisine and beyond-have truly transformed America in some fundamental ways since 1995. These developments, though embraced by many, have also been rejected by others. Indeed, as I have noted elsewhere, racial and cultural change has become the source of great anxiety among many whites, who had long grown used to thinking of themselves (ourselves) as the norm, the prototype, and the very floor model of what an American was. To wit, the Tea Party phenomenon since 2009, replete with mostly white and older Americans, insisted that they intend to "take their country back" from those who they perceive as having hijacked it (Wise, 2012). 
Journal Committed to Social Change on Race and Ethnicity | 2015

As much as the nation has changed, and specifically with regard to its racial makeup and cultural feel, there is yet a remarkable amount of continuity as well. It is a continuity that can be easily missed given the so-called browning of the country, and the rapid pace of transformation ushered in by the Internet and social media, both of which make it seem as though nothing is the same from month to month, let alone decade to decade.

So, for instance, in 2015 few would deny that among the biggest national news stories, those concerning race are front and center in the public consciousness. And this is true not only with regard to the presidency of a man of color, but also with regard to the subject of police treatment of communities of color in the wake of the 2014 killings of Michael Brown in Ferguson, Missouri, Eric Garner in Staten Island, Tamir Rice in Cleveland, and John Crawford outside of Dayton, Ohio, among others. In fact, one could say that in many ways, the issue of how black folks are policed-either by official law enforcement or wanna-be officers like George Zimmerman, the killer of black youth, Trayvon Martin in 2012—has been prominent for the last several years. Most recently, race has burrowed into the national consciousness with the Black Lives Matter movement: initially a web-based "hashtag" campaign on Twitter, but now a grass-roots, community based effort spanning the entire country and involving thousands of activists standing strong against police misconduct, brutality and profiling of black and brown men and women.

Yet, far from a recent development, looking back twenty years one can see that then too, race was prominent in a number of important national news stories. In late 1994, white voters in California—taking advantage of one of the last years in which their 
voting majority would prove decisive in that rapidly browning and now majority of color state-had passed Proposition 187, which sought to restrict public educational and medical expenditures for undocumented migrants. Though proponents of the voter initiative tried to mask the racial and ethnic motivations for the proposition-insisting that they were not anti-immigrant, but simply anti-illegal immigration—-the support garnered from many overtly racist individuals and organizations (and the rhetoric surrounding the Prop-187 campaign, which focused quite explicitly on Mexican migration) made it hard to deny that race was the subtext, if not the explicit text of the story (Chavez, 1998).

So too, in the wake of the vote on Prop-187, voters in California turned up the heat on yet another racially explosive issue-affirmative action-in an attempt to end what they called "racial preferences" for students of color in the University of California system, and other programs designed to steer educational, job and contracting opportunities to persons of color who had for so long been denied them. That Ronald Reagan had actually signed many of those affirmative action programs into law in the waning days of his Gubernatorial administration (Wise, 2005) mattered little to conservatives by the mid-1990s, as they saw attacking affirmative action programs as a politically expedient way to harness white anger and anxiety over so-called "reverse discrimination."

Far from merely a regional issue, race would also take center stage nationally by the fall of 1995; first, after the jury acquitted O.J. Simpson of charges he had killed his ex-wife and one of her acquaintances, and then later that same month, when roughly a million black men gathered in Washington DC for the Million Man March, organized by 
the Nation of Islam's charismatic leader, Louis Farrakhan. In the case of the Simpson verdict, polls suggested that white and black America were deeply divided as to the legitimacy of the jury decision. Most whites were stunned, convinced of Simpson's guilt, even as most blacks celebrated the verdict—not because they necessarily viewed Simpson as innocent, but because they had concerns about the lead detective in the case, who was shown at trial to have displayed a history of racism. The racial split on the verdict was an eye-opening experience for many whites as to how black America views the police, and for at least a year after the trial ended, members of my audiences regularly asked me my opinion about the decision. As I explained to them, putting aside the validity of the verdict, the real issue it seemed-and the one that few seemed willing to engage-was what the racial split told us about our different lenses in this country, and how those lenses are forged in the fires of our racial experiences. If whites and blacks experience law enforcement differently-and indeed within a few years of the Simpson acquittal, the Ramparts division scandal would explode in Los Angeles, in which several members of the Los Angeles Police Department (LAPD) would indeed be found to have planted evidence on criminal suspects of color-then we cannot be surprised when we perceive law enforcement differently.

So too the Million Man March highlighted ongoing racial tensions between whites and blacks, the former of which had long been treated to the demonization of Minister Farrakhan dating back to the 1980 s, and the latter of which, though mostly rejecting Farrakhan's more extreme statements about Jews, for instance-and surely not rushing out to sign up for the Nation—had long viewed him as a courageous voice, uncompromising in his love for black people, and his willingness to confront white 
supremacy without apology. When roughly a million black men began to descend upon the nation's capital that October, there were reports that whites even in the seat of government were all but evacuating the city. White residents were reported to be leaving town, as if fleeing a tsunami. The rally, which was billed as a rather conservative "call to black male responsibility" by its initiators, was yet seen as too radical, divisive, and anti-white by its detractors, even as there was very little talk about white folks at all at the march. All through the fall of 1995 and into 1996, just as audience members would want to know my opinion of the O.J. verdict, they would likewise probe for my views on Farrakhan, who has long served as something of a racial Rorschach test for white America-a bogeyman onto whom we conveniently project our fears and anxieties, and whom we use as a way to deflect attention or concern away from white racism or institutional racial inequity (Wise, 2008).

Far from coincidental, between 1995 and 2015, there have been several other news stories (many of the nation's biggest, in fact) where race was among the key elements in the larger narrative arc. Most prominently, the September 11, 2001 attacks, after which tragedies racial profiling and suspicion towards brown-skinned Muslims and those presumed to be from the Middle East intensified, as well as the flooding of New Orleans in the aftermath of Hurricane Katrina in 2005. In the latter case, the racial divide between whites and blacks in terms of how the incident was viewed was dramatic. Even though the vast majority of persons displaced from their homes had been black (and poor), within a few months of the event most whites were convinced that there was no lesson about racism or racial inequality to be learned from the catastrophe (Ford \& Campbell, 2006). And this whites insisted upon, even as lawmakers in communities in 
Journal Committed to Social Change on Race and Ethnicity | 2015

the New Orleans area openly conspired to prevent blacks from returning and taking up residence (Mock, 2009); even as New Orleans police officers conspired to kill a black man named Henry Glover and cover up their crime (McCarthy, 2010); and even as reports surfaced about white vigilante death squads declaring open season on African Americans found in their neighborhoods in the wake of the flooding (Thompson, 2009).

Finally, even with regard to the arena of higher education there has been some disturbing continuity when it comes to race on campus over the years. In 1990, the year in which I graduated from college, there were two overtly racist incidents on my campus, Tulane University (both of them cross-burnings), and in the most recent academic year there have also been—despite whatever progress we claim to have made as a society—multiple racist incidents on college campuses that have made the news, including most prominently the videotaped fraternity chant at the University of Oklahoma, in which members of the Sigma Alpha Epsilon (SAE) fraternity were caught singing merrily about lynching black people.

Whether in 1995 or 2015 (or for that matter in 1965, 1955 or 1865, truth be told), race has occupied a prominent spot among the nation's most persistently vexing issues. That much has remained the same, year in and year out, generation in and generation out for most of the country's history. The question as regards higher education is to what extent, despite that continuity, quite real demographic and cultural change has altered the way that students and educators talk about race and how race is lived on college campuses-especially for white students whose considerations of race have often been less central to their lives than for persons of color. In this regard, it strikes me that there is both hopeful and disturbing news. 
Journal Committed to Social Change on Race and Ethnicity | 2015

Traveling the country and interacting with college populations for twenty years, I can certainly attest to a shift in the dialogue around race on most campuses. At the outset of my time on the road, most campuses to which I traveled seemed firmly locked in what could be called the "diversity paradigm" of racial conversation. That is to say, they were principally focused on managing demographic change at both the campus and broader national level, hoping to encourage greater tolerance, sensitivity and appreciation for "difference," however defined. Most often the focus on diversity manifested as surface-level interactions around what my friend and colleague Joy Degruy calls "food, fabric and festival"-holiday celebrations, "ethnic food nights," and other performances of cultural difference, intended to inspire a deeper appreciation of "the other." Even the defense of affirmative action typically offered up by those supportive of it tended to be one that emphasized the importance of promoting diversity, so that white students could benefit from interactions with persons of color and thereby develop the competencies needed in an increasingly multicultural nation (Wise, 2005).

Although many colleges and universities are still ensconced in a diversity paradigm some two decades later, I think it no exaggeration to say that in many ways the discussion has progressed, at least at the level of many students, beyond that point. Especially at liberal arts colleges, but even at large research universities and some community colleges as well, I regularly encounter students who are being asked to explore matters of racial inequality and white privilege, in ways I did not in the mid1990s. Whereas then, few white students had even heard the term "white privilege" (let alone been required to read anything on the subject), today the concept, though controversial to some, is bandied about far more readily. Students with whom I meet 
talk about having to discuss white privilege in orientation classes or in their residence halls. Likewise, many staff and administrators have undergone trainings on the subject to heighten awareness about the ways in which white racial identity provides a number of advantages to those able to claim it, and how these advantages get in the way of creating truly equitable educational environments. While some among these may be exaggerating the depth with which they are asked to explore the subject, the ubiquity with which I hear the term readily used on campus today, as opposed to twenty years ago, certainly suggests that at the narrative level, many colleges are moving beyond the diversity paradigm into a more critical "white privilege" paradigm when it comes to racial conversation and consciousness. Indeed, whereas in the mid-1990s, few students I met had even read Peggy Mclntosh's seminal 1988 essay on the subject (Mclntosh, 1988), now I meet hundreds of students each year who were assigned that reading in high school, or early on in college and have since moved well beyond it, often articulating how dated it feels (as should anything written in 1988 I suppose), and providing many more recent examples of white privilege in place of several discussed by Mclntosh in that piece.

While I would hardly suggest that the concept of white privilege is truly understood by most students—let alone accepted as a persistent social reality by most whites on college campuses_-it does appear as though at the level of academic engagement, the conversation around privilege and its meaning has become far more common, and in some cases, even passé. The White Privilege Conference, started in 2000 by Eddie Moore Jr. while a PhD student in lowa, has now grown into one of the most prominent conferences on race in the country, regularly bringing 2,500 
participants—educators and activists alike, along with many young folks from high school through college-together for a four day event to discuss this subject and how campuses and communities may better struggle with its meaning and impact for the cause of racial justice. Even elite private high schools, themselves bastions of race and class privilege, have jumped into the discussion of these subjects, often critically, in an attempt to move their students and the families whence they come to a new place of awareness (Spencer, 2015). Indeed, the concept of white privilege is so prominent now in the nation's racial discourse that even FOX News' Bill O'Reilly has gotten in on the discussion, if merely to lambast it and insist that white privilege doesn't exist. At the risk of being flippant, let it suffice to say that when Bill O'Reilly spends two or three shows trying to debunk the existence of an idea, you can bet that two things are true: first, that the concept has gained enough traction to be worthy of his venom; and second, that the concept in question is undeniably true.

And yet, even as the conversation about race in higher education has shifted somewhat, and even as the discursive component of racial awareness has deepened, I am still struck by how little has been done at the substantive and programmatic level to truly alter systems of privilege. In short, I would suggest that at least from my experience, it appears as though college-age white Americans are being increasingly asked to think about race and white privilege, to understand these issues and be prepared to engage in discourse about them, but not necessarily join in fundamentally transforming the spaces in which this awareness is being raised, from places of privilege and inequality to places of equity and racial justice. We may be asking people to "check their privilege" on social media or in the classroom, but the mechanics of 
Journal Committed to Social Change on Race and Ethnicity | 2015

privilege and inequality are still very much embedded in the policies, practices and procedures of American higher education. Additionally, even those systemic interventions engaged in by some among the nation's colleges and universities, tend to be of a type calculated to bring about interpersonal, more so than institutional, change.

For instance, all across the country I encounter students, faculty, and administrators, who have a fairly developed sense of how their policies, practices and procedures_-from admissions criteria to hiring and tenuring criteria to financial aid to curriculum design—reinforce white advantage. They know this much at least. They understand how selection criteria that reward things like standardized test scores, advanced level high school classes, professional publications and even years of experience, advantage the previously-advantaged, rewarding those who happened to have been fortunate enough to enjoy prior opportunities relative to others who did not. Yet it is the rare student, faculty member of administrator-especially if they are whitewho seems to appreciate the need to actually change those criteria as a result of this recognition, let alone to be involved in an effort to actually make those changes. They see the issue, they can name it, and place it within a larger orbit of "problems to be addressed," but they are loathe to actually move in the direction of changing the way their institutions operate, so as to diminish the privileges to which they can readily point. For whites in these spaces, the thought of actually changing the way the campus looks—beyond bringing in a few Posse Foundation cohorts (students of color from a particular city who are recruited to elite schools in groups), or doing outreach (but even then, typically to elite high schools, private academies and magnet programs, from 
Journal Committed to Social Change on Race and Ethnicity | 2015

which they presume the students will be "qualified" to do college-level work, unlike regular urban public school kids of color)—is a bridge too far.

When schools know full well how their selection instruments maintain inequity, and know that those instruments are horribly inadequate for selecting the best students (FairTest, 2012, 2007, 2007b), they are slow to change. It is the rare college administrator, for instance-as long as there are no big money donors or cameras around-who will actually claim that SAT scores and other standardized tests results are good predictors of student ability. But it is pitifully rare for the nation's most selective institutions, and even some in the middle tier of selectivity, to eschew their use in admissions decisions. They will say they do not place much emphasis on them, but having talked to thousands of students about their prior academic performance, it is the rare student (of color or white) who did not score pretty highly on these tests. School administrators will nod in agreement when discussing the futility of these instruments, and then continue using them anyway, to please parents keen on "selectivity" as an indicator of quality, and to maintain a high ranking with the folks at U.S. News and other ranking organizations. Although there are several schools-including some among the highest ranked liberal arts colleges in America-that have made reporting SAT and ACT scores optional for undergraduate admissions, this is far from the norm; in those schools, the academic criteria used will typically favor those who had prior advantages, having attended schools with advanced curriculum and greater resources than most.

There are proven alternative criteria that can just as effectively select highperforming students (which are far better at promoting diversity and racially equitable representation) (Sedlacek, 2004), few administrators in my experience are willing to do 
much more than nod, or feign fascination with such assessment tools. They are rarely quick to consider actually utilizing them. Even though most colleges and universities operate under mission statements that commit them, at least in theory, to the promotion of "lifelong learning in a global environment," and even diversity (and occasionally, for many schools, even loftier concepts like "justice"), few if any such schools have had deep conversations as to what these principles mean. Even fewer colleges and universities have made concrete moves to operationalize their mission statements, by applying diversity, equity and justice criteria to everything they do, from admissions to hiring to tenuring to graduation requirements. For most institutions, the new paradigm is about acknowledging unearned privilege, rather than truly ending it.

Schools that have committed to some changes in their curriculum (perhaps with a required course or orientation session), or that have promoted community service or service learning, appear to be addressing issues of inequity at more of an interpersonal than truly systemic level. The curriculum changes, unless embedded across the curriculum in an interdisciplinary fashion, will generally reach only that small subset of students who major in disciplines where racial issues figure prominently. One or two survey classes—especially in the first semester or two of college-will at best change a few individual students' worldviews. But they won't change the look of who is sitting in those classrooms or teaching those classes.

Likewise community service often reinforces a charity mindset among students, who go into poor communities to "help," without having first been truly educated as to how those communities became poor in the first place, and how the very advantages they enjoy are the flipside of the disempowerment of those they are now asked to "fix." 
By turning relatively privileged college students loose in such spaces, colleges with the best of possible intentions can nonetheless replicate the very divide they thought to be narrowing. As just one example, a few years ago, after speaking at Marquette University, in Milwaukee, I had the chance to discuss the school's award-winning service learning program with some students of color. Amid many an eye-roll, I was informed that one of the most popular service projects at the college is one in which students (mostly white) go into some of the poorest communities in the city (almost entirely black), and clean up trash. As the students of color explained it-students who steadfastly refuse to participate in this particular service project—white students are regularly confused by the hostility they often experience from community residents who seem not to appreciate having affluent white folks come and clean up after them. At best, such programs reinforce a savior mentality among students (and all the paternalism that comes with that); at worst, they reinforce contempt for the poor and those struggling under the weight of racial and economic marginality. In few cases will such efforts lead to engaged efforts to actually alter the conditions under which such persons labor.

This is not to say that I am without hope as to the potential for higher education to change, or for whites to learn what it means to take our place as one group among mere equals in such spaces. It is simply to say that at present, though we have moved beyond the 101 "diversity" level that was ubiquitous twenty years ago, still too many of our schools appear to be treating issues of racial inequity as academic and intellectual exercises, rather than as subjects for committed institutional action and systemic change. Unless and until there is a sustained movement of students, families, 
Journal Committed to Social Change on Race and Ethnicity | 2015

communities and activists prepared to force colleges to move to more egalitarian policies, practices and procedures, it remains to be seen as to whether those deeper more transformative changes will occur. Just as it took committed and militant activism in the late 1960 s and early 1970 s to force open the doors of many campuses to students of color (and to procure the establishment of academic disciplines addressing the history of marginalized populations), so too will it take committed action to move American higher education—and especially white folks within it—from the "acknowledging privilege" paradigm to one of equity and justice. 


\section{References}

Chavez, L. (1998). The Color Bind: California's Battle to End Affirmative Action.

Berkeley, CA: University of California Press.

FairTest. (2012). What's Wrong With Standardized Tests? FairTest.org. May 12.

FairTest. (2007). SAT I: A Faulty Instrument For Predicting College Success.

FairTest.org. August 20.

FairTest. (2007b). The ACT: Biased, Inaccurate, and Misused. FairTest.org. August 20.

Ford, G. \& Campbell, P. (2006). Katrina: A Study-Black Consensus, White Dispute. The Black Commentator, January 5.

McCarthy, B. (2010). Five NOPD officers indicted in shooting, burning of Henry Glover after Katrina. Nola.com, June 11.

Mclntosh, P. (1988). White privilege and male privilege: A personal account of coming to see correspondences through work in women's studies. (Working Paper No. 189). Wellesley, MA. Wellesley Center for Women.

Mock, B. (2009). Keeping St. Bernard Parish White. The Root, August 25.

Sedlacek, W. (2004). Beyond the Big Test: Noncognitive Assessment in Higher Education. Hoboken, NJ: Jossey-Bass.

Singley, B. (2002). When Race Becomes Real: Black and White Writers Confront Their Personal Histories. Chicago: Lawrence Hill Books.

Spencer, K. (2015) At New York Private Schools, Challenging White Privilege From the Inside. New York Times. February 20.

Thompson, A.C. (2009). New Evidence Surfaces in Post-Katrina Crimes. The Nation, July 20 .

Thompson, C., Schaefer, E., \& Brod, H. (2003) White Men Challenging Racism: 35

Personal Stories. Durham \& London: Duke University Press.

United States Bureau of the Census. (1996). Statistical Abstracts of the United States.

Washington, DC: Government Printing Office.

United States Census Bureau. (2014). Projections of the Population by Sex, Hispanic

Origin, and Race for the United States: 2015 to 2060 (NP2014-T10). December.

Wise, T. (2012) Dear White America: Letter to a New Minority. San Francisco: City Lights Books. 
Journal Committed to Social Change on Race and Ethnicity | 2015

Wise, T. (2010) White Like Me: Reflections on Race from a Privileged Son (Third Edition: The Remix). San Francisco: Soft Skull/Counterpoint Press.

Wise, T. (2008) Farrakhan is Not the Problem: The Arrogance and Absurdity of America's Racial Litmus Test. TimWise.org, May 24.

Wise, T. (2005) Affirmative Action: Racial Preference in Black and White. New York: Routledge. 